\title{
AS GUERRAS JUSTAS NA CRISE DO ANTIGO REGIME PORTUGUÊS ANÁLISE DA POLIITICA INDIGENISTA DE D. JOÃO VI
}

\author{
Fernanda Sposito \\ Doutoranda da FFLCH-USP (bolsista Fapesp) \\ Professora da Fatec-SP
}

\section{Resumo}

Este artigo analisa o sentido da política indigenista entre o final do século XVIII e início do século XIX, especialmente as guerras justas decretadas por d. João VI a partir de 1808 contra os índios de Minas Gerais e São Paulo. Para compreender este movimento, é necessário situá-lo num contexto mais amplo, iniciado pelo Diretório dos Índios de 1757 e encerrado pelo processo de formação nacional brasileiro do século XIX, ambos circunscritos à derrocada do Império português.

\section{Pallavras-chave}

D. João VI • política indigenista $\bullet$ crise do Antigo Regime.

\section{Abstract}

This article analyzes the meaning of the indigenist policy between the end of 18th century and the beginning of 19th century, especially about the guerras justas authorized by d. João VI in 1808 against Indians from Minas Gerais and São Paulo. To understand this movement, is necessary to place it in an ampler context, starting by Diretório dos Índios in 1757 and ending by the process of Brazilian national formation in the 19th century, both related to the collapse of the Portuguese Empire.

\section{Keywords}

D. João VI • indigenist policy $\bullet$ Ancient Regime crisis. 


\section{Guerras contra os índios: modernização ou retrocesso?}

Uma das práticas implementadas pelo príncipe-regente d. João, a partir da vinda da corte lusitana para o Brasil em 1808, é a decretação de guerras justas contra os indígenas, permitindo matá-los ou tomá-los em servidão temporária. ${ }^{1}$ Essa medida aparenta ser um retrocesso em vista das medidas em curso, implicando na reafirmação de alguns dos princípios básicos da colonização praticada há quase três séculos pelos portugueses nesta parte da América. Ora, se seguirmos esta linha de análise, certamente teremos dificuldade de compreender por que as hostilidades contra os índios de São Paulo e Minas Gerais são autorizadas pela Coroa, já que a mesma, quando de sua chegada ao Brasil, adota uma série de medidas modernizadoras, como a quebra do exclusivo comercial, por exemplo. Com isso, coloco a questão de se as guerras justas de $\mathrm{d}$. João representam realmente um recuo em relação às novas práticas em ação há pelo menos meio século e, caso assim seja, em que medida elas se distanciam das demais políticas adotadas pelo governo joanino. ${ }^{2}$

Para enxergá-las como um retrocesso, basta compará-las com a política indigenista de d. José I, implementada pelo seu ministro dos Negócios Estrangeiros e da Guerra, Sebastião José de Carvalho e Mello, marquês de Pombal (1750-1777). No período pombalino, chegou-se a declarar a liberdade indígena em 1755, ainda que o que tenha vigorado tenha sido a proposta de transformar os ameríndios em vassalos do rei, tais quais os demais súditos portugueses dentro da estrutura estamental do Antigo Regime, tão logo fossem civilizados. Partindo desse ponto, é realmente difícil negar que a política joanina representa um recuo diante de tentativas mais pacíficas de submissão dos índios ao Império português.

No entanto, poderíamos resolver de pronto este aparente contrassenso se entendermos que, na verdade, muitas das medidas de Pombal sofrem reveses a

\footnotetext{
${ }^{1}$ Tratam-se das seguintes cartas régias: 13/05/1808. Carta régia ao governador e capitão general de Minas Gerais sobre a guerra aos índios botocudos; e 05/11/1808. Carta régia sobre os índios botocudos, cultura e povoação dos campos gerais de Curitiba e Guarapuava. In: CUNHA, Manuela Carneiro da (org.). Legislação indigenista do século XIX: Uma compilação (1808-1889). São Paulo: Edusp/Comissão Pró-Índio, 1992, p. 58-59; 63. Observação: As citações de documentos da época terão sua grafia corrigida para as normas de grafia atuais, mantendo, no entanto, a pontuação original. ${ }^{2}$ D. João, embora tenha assumido o reinado de sua mãe, d. Maria I, em 1792, somente em 1799 é nomeado príncipe-regente do Império português, momento em que não se acredita mais na possibilidade de recuperação das enfermidades da rainha. Dois anos após a morte dela, em 1818, ele é coroado rei com o nome de d. João VI. Seu reinado no Brasil vai até 1821, quando passa o trono do Brasil a seu filho d. Pedro e estabelece-se em Portugal até 1826, ano de sua morte. SERRÃO, Joel. Dicionário de história de Portugal. Porto: Figueirinhas, vol. 3, 2002.
} 
partir da Viradeira, com o reinado de d. Maria I (1777-1799), visto que o despotismo esclarecido ou o reformismo ilustrado perdem espaço ante o predomínio de um governo menos reformador e disposto a restaurar antigos privilégios aristocráticos e coloniais. Um exemplo disso, lapidar para a questão indígena, é que as agressões diretas aos ameríndios voltam a ser permitidas já em 1798, com a revogação do Diretório dos Índios de 1757. De todo modo, a leitura dos governos de d. Maria I e de d. João como períodos exclusivamente de conservadorismo não procede, visto que o abalo das estruturas do Antigo Regime está em curso, obrigando a convivência tensa e dúbia entre o moderno e o arcaico. ${ }^{3}$

A política joanina começa a fazer sentido, portanto, quando passamos a perceber o seu reinado como o auge da crise do Antigo Regime português, na qual o sistema colonial praticado na América não se sustenta mais, abalado pelos novos arranjos políticos e econômicos propiciados pelas revoluções burguesas. ${ }^{4} \mathrm{Neste}$ momento, as práticas coloniais ainda são elementos propulsores do Império luso que, no entanto, vê-se seriamente ameaçado na medida em que as mudanças políticas e econômicas em jogo - tais como a independência dos Estados Unidos, a Revolução Francesa e a Revolução do Haiti - requerem adaptações crescentes às demandas do capital industrial vigente no final do século XVIII. Posteriormente, o ajuste aos novos tempos, mesmo após o rompimento com a metrópole e com o início da construção nacional brasileira, ainda traria os resquícios desse passado colonial, conforme sentenciou Sérgio Buarque de Holanda. ${ }^{5}$

\footnotetext{
${ }_{3}^{3}$ Ana Rosa Cloclet da Silva nota, no período mariano, com a Viradeira, a tentativa de restaurar alguns privilégios aristocráticos desmontados com as reformas pombalinas. Mas analisa que o sentido geral das mudanças estabelecidas anteriormente permanece inalterado. SILVA, Ana Rosa Cloclet da. Inventando a nação: Intelectuais ilustrados e estadistas luso-brasileiros na crise do Antigo Regime português. São Paulo: Hucitec/Fapesp, 2006, p. 105-106.

${ }^{4}$ A mais precisa síntese desse processo continua sendo de Fernando Novais: "Sob esse aspecto, o reinado de d. Maria I apresenta-se, pois, mais bafejado pelas Luzes do que o período anterior. É todo um difuso programa de reformas que se preconiza, um esforço mais ou menos dramático de reajustamento às tendências dominantes, com vistas à dinamização da sociedade, sem contudo atingir as suas estruturas fundamentais: reformismo típico e de resto ineficaz. Nem o projeto pôde com efeito amadurecer plenamente e objetivar-se em profundidade, alcançado o país pelas hostes napoleônicas, produtos elas próprias dos desdobramentos da revolução liberal em curso. Do consulado pombalino à vinda do príncipe regente para a América transita-se nas águas revoltas da crise geral do Antigo Regime e do sistema de colonização mercantilista." NOVAIS, Fernando A. Portugal e Brasil na crise do antigo sistema colonial. (1777-1808). $7^{\text {a }}$ ed. São Paulo: Hucitec, 2002, p. 10-11. ${ }^{5}$ HOLANDA, Sérgio Buarque de. A herança colonial, sua desagregação. In: HOLANDA, Sérgio Buarque de (org.) História geral da civilização brasileira, tomo 2, vol. 1. Rio de Janeiro: Bertrand Brasil, 1997, p. 10-39.
} 
Para o que interessa aos limites deste artigo, analisando as tentativas de superação dessa crise sistêmica, tem-se a busca da Coroa portuguesa em manter seu Império, especialmente o Brasil, sua colônia mais rica, ainda que para isso fosse necessário transferir a corte para a América. A partir desse movimento, precipitado pela invasão francesa a Lisboa em 1807, coloca-se o enfrentamento direto dos grandes dilemas da crise. De um lado, a garantia da posse da colônia frente aos inimigos externos, as potências estrangeiras em disputa na Europa, pressionando pela abertura dos mercados coloniais. De outro, o controle dos inimigos internos, como os povos indígenas em regiões distantes dos centros urbanos, ameaçando as fronteiras do Império, os escravos africanos e as diferentes identidades geridas ao longo da colonização que, durante este período, enfrentarão o poder régio. ${ }^{6}$

Para analisar como as práticas da Coroa com relação às populações ameríndias foram definidas, pretendo aprofundar-me nas variáveis presentes durante o governo pombalino e, posteriormente, no reinado de d. Maria I - d. João VI. Procurarei perceber, nos limites de alcance deste artigo, quais questões se colocavam para as populações indígenas onde os conflitos eclodiram, nas regiões mais afastadas dos centros habitados pelos luso-brasileiros em Minas Gerais e São Paulo, os chamados "sertões dos botocudos". ${ }^{7}$ Percorrido este trajeto, acredito ser possível repensar algumas proposições a respeito da política indigenista colonial.

A adoção do par dicotômico "modernização ou retrocesso", colocado no subtítulo acima como modelo explicativo, é certamente uma opção metodológica arriscada. Embora reconheça as simplificações possíveis de serem feitas quando se analisa um processo histórico utilizando-se categorias estanques ou propagandísticas, como "moderno" ou "arcaico", assumo aqui o risco desta opção. Justamente porque não pretendo pensá-las como uma coisa ou outra, mas demonstrar que a política indigenista joanina traz em si as dinâmicas de

\footnotetext{
${ }^{6}$ Sobre as identidades regionais que teriam que ser enquadradas durante a formação nacional brasileira, ver JANCSÓ, István e PIMENTA, João Paulo G. Peças de um mosaico ou apontamentos para o estudo da emergência da identidade nacional brasileira. In: MOTA, Carlos Guilherme (org.). Viagem incompleta: A experiência brasileira (1500-2000). Formação: histórias. $2^{a}$ ed. São Paulo: Senac, 2000, p. 129-175. ${ }^{7}$ Embora tenha se convencionado denominar genericamente "botocudos" alguns grupos indígenas de Minas Gerais e "bugres" os de São Paulo, a própria carta régia de 05/11/1808 para São Paulo enuncia essas populações também como "botocudas". Também em minha dissertação de mestrado, analisando as populações presentes na Província de São Paulo, entre os anos 1820 e 1840, percebi várias classificações de grupos como "botocudos", os quais identifiquei como kaiowás e guaranis, devido ao tembetá que usavam, perfurando o queixo. Ver: SPOSITO, Fernanda. Nem cidadãos, nem brasileiros. Indígenas na formação do Estado nacional brasileiro e conflitos na Província de São Paulo (18221845). Dissertação de mestrado, História Social, FFLCH, Universidade de São Paulo, 2006, cap. 4.
} 
seu tempo, dialoga, interfere e é alterada pelas transformações oriundas da crise do Antigo Regime, sejam revolucionárias ou regressistas. Partir deste par dicotômico, portanto, torna-se necessário para compreender as disputas sociais envolvendo as populações indígenas no período em que, por sua vez, expressam diferentes projetos políticos. Para fugir, portanto, de uma visão homogeneizante a respeito da política indigenista, que pretende lamentar o genocídio dos índios, sem atentar para as diferentes propostas e práticas, tanto por parte dos agentes coloniais quanto dos ameríndios, proponho aqui uma perspectiva comparativa entre diferentes modelos de política indigenista. Ao mesmo tempo, tento inserir essa contraposição de propostas no tempo de crise em que foi gerada, contextualização esta que, inerente à prática do historiador, dá sentido a este estudo.

\section{Pombal e a liberdade tutelada}

Decerto que, para poder compreender o sentido das mudanças ou permanências, é preciso saber quais eram os critérios pelos quais se pautavam as relações entre os colonizadores e os diversos povos indígenas habitantes da América portuguesa nos séculos anteriores. Ao debruçar sobre a questão indígena no período colonial, é difícil escapar da tipificação elementar que fizeram os colonizadores a respeito dos nativos da América a partir das primeiras décadas do século XVI. Trata-se da classificação dos índios em dois grandes grupos: os chamados "tupis" e os denominados "tapuias" que, se não se enquadram exatamente num sério critério etnológico, funcionam com perfeição para os intentos dos agentes coloniais efetivarem o domínio sobre essas terras e gentes. ${ }^{8}$

Segundo essa classificação, os povos da costa atlântica foram reconhecidos como pertencentes a um mesmo grande grupo que foi denominado de tupi. Os que eram inimigos destes, que habitavam geralmente o interior do território americano, foram identificados como tapuias. Segundo os conhecimentos atuais sobre os indígenas, pautados pela etnologia, essa classificação pode ser justificada pelo fato dos povos chamados genericamente tupis serem povos falantes do tronco linguístico tupi-guarani, composto de idiomas semelhantes. No sentido inverso, os demais povos que não podiam ser enquadrados dentro dessa família linguística, pertenceriam ao tronco linguístico classificado posteriormente como macro-jê, englobando etnias

\footnotetext{
${ }^{8}$ Essa classificação é reiterada por vários cronistas do início da colonização da América portuguesa como Pero de Magalhães Gândavo (1575), José de Anchieta (1584), frei Vicente do Salvador (1627), dentre outros.
} 
que não guardavam tantas semelhanças de idioma nem de costume, mas principalmente o fato de não serem do tronco tupi. Tomar contato com essa categorização é importante para o estudo em foco, pois o critério de inimizade dos colonizadores contra uma determinada etnia, como os chamados botocudos do século XIX, era justificado com base nessa classificação que fazia os índios da costa serem normalmente aliados dos brancos e os povos do interior serem tachados de inimigos cruéis. E foi essa divisão que respaldou, em larga medida, a política indigenista colonial, ainda que, muitas vezes, aos tupis foram atribuídas características dos tapuias e vice-versa, para justificar agressões a determinado grupo.

Grosso modo, essa maneira bipolar de enxergar a composição étnica dos ameríndios implicou em dois tipos de posturas por parte dos agentes da colonização portuguesa, ainda que ambas buscassem o controle e a submissão desses povos. Assim, aos chamados tupis, muitos destes grupos realmente aliados de extrema importância na construção e consolidação da empresa colonial nestas terras, a civilização e a conversão à religião católica, seguindo a concepção de que estes povos deveriam ser salvos. Aos ditos tapuias, o oposto disso; poder-se-iam praticar guerras contra eles, já que eram vistos como empecilho ao avanço da ocupação lusa. Contra estes inimigos, estavam autorizadas tanto sua morte quanto sua escravização. Assim, as chamadas guerras justas eram práticas hostis por parte dos colonizadores, justificadas na medida em que estes povos impediam a propagação da fé católica, ao rechaçarem a presença dos conquistadores europeus, sendo adeptos de ritos que os faziam se aproximar de figuras demoníacas segundo o imaginário cristão, já que eram antropófagos e polígamos, argumentação baseada na versão dos portugueses, pois, como veremos mais à frente, geralmente os antropófagos eram tupis. ${ }^{9}$

Como resumo da história de mais de 200 anos de contato que antecede a política pombalina, tem-se uma legislação a respeito dos povos indígenas que reflete justamente esse quadro multifacetado de agentes e interesses diversos presentes no cenário colonial. ${ }^{10}$ Aos diferentes grupos, às vezes a aliança com os

\footnotetext{
${ }^{9}$ Sobre a questão da guerra justa, as colocações de Perrone-Moisés são extremamente úteis. Ver: PERRONE-MOISÉS, Beatriz. Verdadeiros contrários: guerras contra o gentio no Brasil colonial. In: Sexta-Feira, v. 7. São Paulo, 2003, p. A24-A34.

10 "Como sugeriu Beatriz Perrone-Moisés, a ideia de uma legislação 'tortuosa e crivada de contradições' deve ser substituída por uma percepção das diferenças com que eram tratados os grupos indígenas considerados aliados, isto é, compreendidos como participantes das estratégias da consolidação do domínio, e aqueles considerados inimigos, ou seja, que se recusavam àquela estratégia ou, simplesmente, foram destinados ao trabalho forçado. Assim, como diz a antropóloga,
} 
invasores poderia ser interessante frente às disputas interétnicas preexistentes. Entre os agentes coloniais, uma das principais polarizações a respeito dos índios deu-se entre os jesuítas e os colonizadores laicos - fazendeiros, criadores de gado, negociantes, funcionários régios etc. Enquanto os padres lutavam para evangelizá-los e mantê-los nos aldeamentos sob seu controle, os particulares buscavam tê-los em suas propriedades, normalmente como escravos. Para estes últimos, portanto, as guerras justas eram fundamentais. Além disso, essas guerras de agressões, autorizadas pela Coroa, também serviam para eliminar obstáculos ao avanço da empresa colonial, especialmente nas regiões de economia mais integrada ao grande mercado mundial, que era guarnecido principalmente pelo escravo africano, num lucrativo negócio iniciado na América ainda no século XVI, como forma de interligar o comércio atlântico. ${ }^{11}$ Longe, então, de representar uma política oscilante e descaracterizada, as leis a respeito dos índios indicaram claramente a presença dos vários movimentos e interesses, fortemente conflitantes, presentes no Império português. Ressalto aqui que dinâmica não quer dizer oscilação e indefinição, mas sim que a prática legal respondeu historicamente às demandas presentes nas estruturas sociais às quais corresponderam.

O que faz o marquês de Pombal quando assume o Ministério dos Negócios Estrangeiros em 1750, é justamente redefinir o encaminhamento dado à questão indígena, procurando adotar um novo modelo de tratamento a esses povos. Isso significa torná-los vassalos do rei, integrando-os ao Império, o que impede, logicamente, a sua escravização. Interpreto a política pombalina pelo viés de ruptura, visto que ela golpeia os fundamentos das medidas régias anteriores

\footnotetext{
'à diferença irredutível entre 'índios amigos' e 'gentio bravo' correspondeu um corte da legislação e política indigenista'. Nádia Farage, estudando a política indigenista portuguesa no século XVIII, mostrou a correlação que existia entre a definição da área de domínio português e o estreitamento dos laços de vassalagem com os povos nativos. É o 'peso político-estratégico' atribuído aos índios que definiria a 'oscilação' da legislação portuguesa. A bipolaridade tupi-tapuia, marca fundamental da percepção da diversidade dos povos indígenas pelos colonizadores, estava no cerne desta problemática, representando o corte entre aliados e inimigos, não só no imaginário, como nos contextos concretos." PUNTONI, Pedro. A guerra dos bárbaros: Povos indígenas e a colonização do sertão nordeste do Brasil (1650-1720). São Paulo: Hucitec/Edusp/Fapesp, 2002, p. 60-61.

${ }^{11}$ Há um certo consenso na historiografia mais recente de que a utilização de mão-de-obra indígena em grande escala deu-se particularmente nas regiões mais pobres da colônia, onde o tráfico de escravos africanos não podia ser implementado por questões econômicas. NOVAIS, Fernando A. Portugal e Brasil na crise do antigo sistema colonial, op. cit., p. 103-106; MONTEIRO, John Manuel. Negros da terra: Índios e bandeirantes nas origens de São Paulo. São Paulo: Companhia das Letras, 2000, p. 55-58. ALENCASTRO, Luís Felipe. O trato dos viventes: Formação do Brasil no Atlântico Sul. São Paulo: Companhia das Letras, 2000 - especialmente o capítulo 4, "Os índios, os 'escravos da terra'."
} 
que, vez por outra, procuravam atender pelo menos um dos lados da contenda. ${ }^{12}$ No entanto, alguns autores atribuem ao indigenismo pombalino a reedição de outras práticas protecionistas dos séculos anteriores. ${ }^{13}$ Essa não me parece ser a leitura mais precisa a respeito desse processo, que está inserido num contexto bem marcado do período colonial, de enfrentamento dos limites desse sistema, motivado pelas crises econômicas e pelo acirramento das tensões entre metrópole e colônia. Como demonstra Iris Kantor, as redefinições territoriais e administrativas do território americano estão dentro dos projetos de reenquadramento da colônia ao Império português. ${ }^{14} \mathrm{O}$ próprio Pombal avisa ao governador do Rio de Janeiro, no contexto da demarcação das fronteiras do território americano com o Império espanhol, o quão importante é a participação das populações indígenas para o êxito desse processo, pois a "força e a riqueza de todos os países consistem principalmente no número e multiplicação da gente se faz indispensável agora na raia do Brasil para a sua defesa". Para isso, é necessário

\footnotetext{
${ }^{12}$ Mauro Cezar Coelho não nega o caráter opressivo contra as populações indígenas que continuou a pautar as medidas régias, no entanto, ressalta o caráter revolucionário do Diretório, ao chamar essas populações para contribuírem com a ocupação e a exploração do espaço colonial. COELHO, Mauro Cezar. Do sertão para o mar: Um estudo sobre a experiência portuguesa na América, a partir da colônia. O caso do Diretório dos Índios (1751-1798). Tese de doutorado, História Social, FFLCH, Universidade de São Paulo, 2005, p. 245.

${ }^{13}$ Sobre o questionamento da radicalidade do Diretório, tanto Nádia Farage como Rita Heloísa de Almeida, que fizeram importantes estudos a respeito do contexto de elaboração do Diretório, enxergamno como uma reedição de medidas adotadas pela Coroa anteriormente, como o Regimento das Missões de 1686. FARAGE, Nádia. As muralhas do sertão: Os povos indígenas no Rio Branco e colonização. Rio de Janeiro: Paz e Terra/Anpocs, 1991, p. 26-34 e ALMEIDA, Rita Heló́sa de. O Diretório dos Índios: Um projeto de "civilização" no Brasil do século XVIII. Brasília: Ed. UnB, 1997, p. 321-350. ${ }^{14}$ A respeito do contexto pombalino, a análise de Iris Kantor sintetiza pontos centrais das transformações em voga: "O Tratado de Madri (1750), a expulsão dos jesuítas (1759) e a transferência da capital do Estado do Brasil de Salvador para o Rio de Janeiro (1763) desencadearam um movimento de reterritorialização da soberania lusa no continente sul-americano. Por sua vez, o processo de demarcação das fronteiras entre portugueses e espanhóis exigiu a expansão das estruturas administrativas (tanto civis, como eclesiásticas) no interior do território. A necessidade de enraizar a rede administrativa levou à elevação de novas vilas nos sertões e áreas de ocupação recente, como, também, à ampliação da malha paroquial e judicial (comarcas e ouvidorias). Tais medidas implicavam um esforço de demarcação dos limites territoriais entre as capitanias, bispados e comarcas, cujas circunstâncias eram fluidas a ponto de criar tensões de toda ordem, sobretudo no âmbito tributário e fiscal. No campo militar, a construção de fortalezas e a reforma dos regimentos militares reforçaram a diretriz estabelecida pelo Diretório dos Índios, a qual pretendia transformar o índio em vassalo útil ao pagamento do dízimo, composição das tropas militares e ocupação das fronteiras litigiosas." KANTOR, Iris. Legislação indigenista, reordenamento territorial e autorrepresentação das elites (1759-1822). In: KOERNER, Andrei (org.). História da Justiça Penal no Brasil: pesquisas e análises. São Paulo: IBCCRIM, 2006, p. 29-30.
} 
o fim de "toda diferença entre Portugueses e Tapes (índios), privilegiando e distinguindo os primeiros quando casarem com filhas dos segundos". ${ }^{15}$

Dentro desse processo, especialmente no norte da colônia portuguesa, o Estado do Maranhão e Grão-Pará, a população indígena adquire uma centralidade bem particular devido à ampla dimensão demográfica que representa e sua importância fundamental nas atividades de exploração colonial, sendo pensada como uma solução para superação dessa crise. A administração régia, ainda que faça algumas concessões, atinge privilégios tanto de particulares como de religiosos e propõe um caminho bastante claro a respeito do papel que devem representar os índios dentro do Império português setecentista. A figura de Francisco Xavier de Mendonça Furtado, irmão de Pombal e governador do reformulado Estado do Grão-Pará e Maranhão, é peça-chave desse processo, já que é o articulador das transformações em jogo nesta região e que são depois ampliadas para toda a América portuguesa. Em 6 de junho de 1755, d. José I decreta a liberdade indígena e no dia seguinte pró́be a administração religiosa dos índios. ${ }^{16}$ Enquanto os jesuítas, sustentáculo fundamental do aparato de conversão religiosa nos séculos anteriores, têm extinguido seus direitos na América, os particulares muito resistem à implementação da liberdade indígena, o que acaba por impedir sua plena adoção. Tão forte é sua resistência ante a possibilidade de perderem o acesso à mão-de-obra ameríndia que a proposta da liberdade plena é cancelada, conforme se pode depreender da aprovação do "Diretório dos Índios", na verdade "Directorio que se deve observar nas Povoaçoens dos Indios do Pará e Maranhão, enquanto Sua Magestade não mandar o contrário" de 1757. ${ }^{17}$

A resistência dos moradores à liberdade dos índios, impossibilitando-os de manterem o seu plantel de escravos, de repô-los ou ampliá-los, reflete-se na lei de 1757. O Diretório coloca-se como uma outra forma de controle sobre essas populações, mesmo que a Coroa previsse a vinda de africanos como substitutos

\footnotetext{
${ }^{15}$ Primeira carta secretíssima de Sebastião José de Carvalho e Melo, para Gomes Freire de Andrada, para servir de suplemento às instruções que lhe foram enviadas sobre a forma de execução do Tratado Preliminar de Limites, assinado em Madri a 13 de janeiro de 1750, Lisboa, 21/09/1751, citado por SILVA, Ana Rosa Cloclet da, op. cit., 2006, p. 89.

${ }^{16} 06 / 06 / 1755$. Ley porque V. Magestade ha por bem restituir aos Indios do Graõ Pará, e Maranhaõ a liberdade das suas pessoas, bens e commercio na fórma que nella se declara. In: MOREIRA NETO, Carlos de Araújo. Índios da Amazônia: de maioria a minoria (1750-1850). Petrópolis: Vozes, 1988, p. 152-162. FARAGE, Nádia, op. cit., 1991, p. 34-9.

${ }^{17}$ Directorio que se deve observar nas Povoaçoens de Índios do Pará e Maranhão, enquanto Sua Magestade não mandar o contrário. MOREIRA NETO, Carlos de Araújo, op. cit., 1988, p. 166-205.
} 
à mão-de-obra nativa, com a formação da Companhia Geral de Comércio do Grão-Pará e Maranhão de 1755, não por acaso promulgada no mesmo momento da declaração da liberdade indígena. ${ }^{18} \mathrm{O}$ mecanismo proposto pelo Diretório é realmente engenhoso e a figura do diretor de aldeia - um administrador temporal presente em cada comunidade indígena, funcionando como um mediador dos índios junto à sociedade colonial, a fim de civilizá-los - cria o elo que faltava para manter a estrutura de dominação. A partir de então, a noção de tutela passa a vigorar, categorizando o índio como incapaz de reger a si próprio dentro da sociedade estamental, para isso necessitando de um representante de seus interesses junto aos poderes instituídos. O fundamento de tutela, que remonta, portanto, ao período colonial, está presente até os dias atuais, ainda que hoje o sentido não seja de civilizar o índio, mas, teoricamente, protegê-lo de interesses que atentem contra sua sobrevivência física e cultural.

A tutela não permite a equivalência legal dos índios em relação aos demais súditos do Império português e é expressa por dois dispositivos: a criação do diretor laico nas aldeias e a colocação dos indígenas sob o controle do juiz de órfãos. Através deste segundo mecanismo, os índios são assumidos como incapazes e o juiz pode autorizar, quando solicitado, a permissão a particulares para mantê-los em sua propriedade, continuando sua exploração, sob a justificativa disfarçada de estarem instruindo os ameríndios para entrarem na sociedade portuguesa. Foi Nádia Farage quem melhor sintetizou esse movimento.

Abro aqui uns parênteses para acrescentar que a saída legal de que o Estado lança mão nesse momento para assegurar o fornecimento de uma mão-de-obra formalmente livre, colocando-a sob a administração do juiz de órfãos, teve profunda repercussão na condição jurídica posteriormente atribuída à população indígena:

\footnotetext{
18 “As autoridades temiam reações violentas por parte da população do Estado do Grão-Pará e Maranhão quando se visse privada da sua principal fonte de trabalho e rendimentos. Este perigo era tão mais premente quando se adivinhava que pouca colaboração para dominar uma possível revolta poderia advir dos militares, também eles detentores de escravos índios. Como se sabe, a sociedade colonial protestou violentamente. Para além das manifestações formais endereçadas à Coroa e ao governador, comprovou-se a existência de uma aliança entre alguns moradores e a Coroa francesa, na qual os colonos prometiam a cedência do Estado do Norte brasileiro ao rei de França, conquanto este se comprometesse a manter o estatuto da escravidão indígena. Os envolvidos eram designados como sendo homens rústicos e tirados do mato. Simultaneamente, insinuava-se o envolvimento da Companhia de Jesus, pela participação do padre Hundertpfundt na traição.” DOMINGUES, Ângela. Quando os índios eram vassalos: Colonização e relações de poder no norte do Brasil na segunda metade do século XVIII. Lisboa: Comissão Nacional para as Comemorações dos Descobrimentos Portugueses, 2000, p. 45-46.
} 
a carta régia de 12.05.1798 veio a abolir o sistema do Diretório, mas manteve os índios na condição de órfãos, entendendo que este seria um "privilégio" que lhes concedia o Estado, como forma de protegê-los no trato com os brancos. ${ }^{19}$

A partir desse ponto, entramos no questionamento que o projeto pombalino vive à época, vítima de inúmeras críticas, cuja veracidade merece ser relativizada, uma vez que muitos dos que acusam os diretores dos índios de serem ineptos e gerarem a decadência dos aldeamentos, estão buscando justamente obter o controle sobre estes índios. Esse é ponto central - o controle sobre os índios que parece ter orientado as medidas de d. Maria I que, no final do século XVIII, revoga o Diretório e elimina os intermediários que pudessem atuar na integração desigual dos índios à sociedade portuguesa, segundo a lei de 1798 citada acima. Fica-nos o dilema se o fim do Diretório significa, necessariamente, o término dessa possibilidade de inclusão do indígena ao universo português, logicamente que dentro de uma condição subalterna, pois que se tratava de uma sociedade do Antigo Regime, o que, portanto, não pressupunha a igualdade jurídica ou social, apenas a condição de todos serem protegidos e deverem obrigações ao soberano. Vejamos como essa lei se justifica a si própria. ${ }^{20}$

Hei por bem abolir e extinguir de todo o diretório dos índios estabelecido provisionalmente para o governo econômico das suas povoações para que os mesmos índios fiquem sem diferença dos outros meus vassalos, sendo dirigidos e governados pelas mesmas leis que regem todos aqueles dos diferentes estados que compõem a monarquia, restituindo os índios aos direitos que lhes pertencem igualmente como os meus vassalos livres. ${ }^{21}$

Esse enunciado, por si só, não nos permite crer que a condição do indígena tenha realmente melhorado, mas, talvez, que os entraves legais colocados pelo Diretório para a plena entrada dos índios na sociedade colonial e a exploração de sua mão-de-obra tenham sido derrubados. A carta-régia de 1798, também projetada inicialmente para a região amazônica, coloca duas formas de procedimento com relação às populações indígenas, dependendo de os índios serem

\footnotetext{
${ }^{19}$ FARAGE, Nádia, op. cit., 1991, p. 47-48.

${ }^{20}$ Um texto que analisa mais detidamente esta lei de 1798, contextualizando-a na Amazônia portuguesa, é o de SAMPAIO, Patrícia Melo. Administração colonial e legislação indigenista na Amazônia portuguesa. In: PRIORE, Mary del; GOMES, Flávio (orgs.). Os senhores dos rios: Amazônia, história e margens. Rio de Janeiro: Campus, 2003, p. 129-140.

${ }^{21}$ Carta régia de 12 de maio de 1798 sobre a civilisação dos indios. In: Revista do Instituto Histórico e Geográfico Brasileiro, tomo 19. Rio de Janeiro: Laemmert, 1856, p. 314.
} 
aldeados, misturados aos brancos, ou, ao contrário, estarem nas matas, longe das povoações portuguesas.

Os aldeados podem ser engajados para compor as forças armadas da região, seja nos corpos de milícias, ou em companhias de pedestres. É previsto que pudessem ser incorporados às expedições de comércio do Pará ao Mato Grosso e também entrarem nas companhias de pesca, mecanismo central de abastecimento alimentício no norte. ${ }^{22}$ No entanto, a grande novidade, que inclusive passa a ser utilizada como um instrumento político dos indígenas já misturados à sociedade ocidental, é a proibição do ouvidor das vilas e cidades de usar indígenas como operários para os serviços de particulares (ou seja, "apenar"), caso estes índios fossem d' “aqueles indivíduos que tiverem estabelecimentos próprios, e de um valor determinado, nem tão pouco será lícito ao mesmo ouvidor apenar os operários precisos para irem trabalhar fora dos seus distritos respectivos". ${ }^{23}$ Claro que para os outros índios, que não têm suas terras individuais ou familiares demarcadas, fica difícil evitar legalmente a prestação de serviços compulsórios, ou seja, sua escravização. Mas essa salvaguarda aos demais é um marco político para as populações indígenas na região. ${ }^{24}$ Por sua vez, aos índios das matas, estão proibidas hostilidades, guerras ofensivas e os descimentos (comboio de indígenas de regiões distantes que eram trazidos pelos colonizadores às vilas e cidades para serem "civilizados" nos aldeamentos ou nas propriedades particulares). Estes índios recebem da rainha o privilégio de órfãos, sobre os quais cabem a proteção real e a proibição de sua escravização.

Em síntese, tem-se que os índios aldeados, misturados à população, são livres, ainda que haja uma série de exceções que permitem aos particulares e à Coroa solicitarem seu trabalho. Os índios das matas são, ao contrário, ainda mantidos sob tutela pelo reino, visto que são considerados órfãos e incapazes de responderem por seus atos. É interessante perceber que o princípio central do

\footnotetext{
${ }^{22}$ Idem, ibidem, p. 315-316.

${ }^{23}$ Idem, ibidem, p. 319.

${ }^{24}$ André Roberto Arruda Machado, problematizando as populações indígenas no Grão-Pará nas primeiras décadas do século XIX, mostra como as populações já misturadas aos colonizadores, os chamados tapuios, utilizar-se-ão de ferramentas legais, como deliberações das Cortes de Lisboa em 1821, para evitar serem obrigados a prestar serviços aos particulares e serem recrutados. É uma questão interessante para se pensar se a lei de 1798 também não teria sido instrumentalizada algumas décadas antes. MACHADO, André Roberto de Arruda. A quebra da mola real das sociedades: A crise política do Antigo Regime português na Província do Grão-Pará (1821-1825). Tese de doutorado, História Social, FFLCH, Universidade de São Paulo, 2006, p. 60-70.
} 
Diretório mantém-se com esta política, ou seja, as tentativas de incorporação do índio à sociedade portuguesa, pela via da miscigenação, da prestação de serviços, dos "bons modos" e não por escravização ou vias ofensivas. As guerras são permitidas aqui, mas com um caráter de exceção. Mesmo assim, isso não nos autoriza pensá-las como uma ruptura tão grande com relação ao Diretório.

(...) e só vos será lícito adotar um sistema diferente deste puramente defensivo, no caso em que algumas das mesmas nações intentem hostilidades e correrias contra as cidades, vilas e outras povoações, de sorte que os mesmos cabos encarregados de defenderem o país ameaçado ou já atacado ficarão responsáveis e sujeitos a uma devassa para se averiguar se eles excederam as ordens que vós deveis dar-lhes de se manterem na mais estrita defensiva, e ainda no uso dela tão moderado que aos índios se faça ver que eles o atacam e acometem uns homens que bem longe de lhes quererem mal apenas procuram defender as vidas, e preservar-se das suas correrias. ${ }^{25}$

Poderíamos interpretar essa lei como uma perda para as populações indígenas, se entendermos que os diretores das aldeias realmente foram intermediários no processo de assimilação e conversão dos indígenas ao universo português. Se assim fosse, os diretores estariam protegendo os direitos dos índios, assegurando o pagamento dos seus serviços, evitando que fossem enganados pelos lusos, o que nem sempre ocorria, segundo seus críticos coevos que, por sua vez, estavam envolvidos nas disputas pelo controle dos índios. ${ }^{26}$ Acredito, então, que a lei de 1798 não destoa do espírito que norteou o Diretório pombalino, embora propusesse outros meios para a incorporação dos índios ao Império português que podemos até julgar como menos protecionistas. A questão central para este artigo é que a incorporação se dava, ao menos na intencionalidade de ambas

\footnotetext{
${ }^{25}$ Carta régia de 12 de maio de 1798 sobre a civilisação dos índios, op. cit., 1856, p. 321.

${ }^{26}$ Segundo o levantamento feito por Ana Paula Medicci a respeito de várias autoridades e intelectuais luso-brasileiros entre o final do século XVIII e início do XIX, vê-se que eles apontam o indígena como solução para uma suposta decadência econômica da capitania paulista e criticam os princípios do Diretório, propondo outra forma de se apropriar dessa mão-de-obra. Como nota a autora, a maioria desses autores critica a ação dos diretores que consideram maltratar os índios, mas contraditoriamente, não reclama da política de guerra justa contra os índios, esta sim muito mais agressiva a essa população. Isso indica que muito menos interessadas em proteger os direitos indígenas, essas autoridades objetivavam garantir meios de se apropriar dessa mão-de-obra mais facilmente. MEDICCI, Ana Paula. Entre a "decadência” e o "florescimento": A capitania de São Paulo na interpretação de memorialistas e autoridades públicas (1782-1822). Dissertação de mestrado, História Social, FFLCH, Universidade de São Paulo, 2005, p. 156-157. Ver também MONTEIRO, John Manuel. A memória das aldeias de São Paulo. Índios, paulistas e portugueses em Arouche e Machado de Oliveira. In: Dimensões: Revista de História da UFES, 14, 2002, p. 17-35.
} 
as leis, de maneira atrativa, não ofensiva. Já não se pode dizer o mesmo das medidas de d. João que, alguns meses depois de sua chegada ao Brasil, decreta guerras contra aqueles aos quais acusa de serem sanguinários, para os quais somente o terror das armas reais os faria submissos ${ }^{27}$ Sob palavras de tão forte apelo discursivo, parece indubitável que, a partir de então, passa a haver outros meios e fins para justificar o controle sobre essas populações.

\section{A chegada da corte: transformações e tensões}

A chegada da família real portuguesa à sua colônia mais rica em 1808 demarca o movimento duplo de buscar manter os velhos privilégios, readequando-os aos novos tempos. Assim, não se pode mais pensar o traslado da corte para a América como um movimento de "interiorização da metrópole", conforme havia proposto Maria Odila da Silva Dias, porque atribuir a manutenção da figura metropolitana mesmo a partir de 1815, com a elevação do Brasil à condição de Reino Unido a Portugal e Algarves, ressalta muito mais as continuidades do que as rupturas no processo em vigor. ${ }^{28}$ Assim, o Rio de Janeiro, alçado a sua nova condição de corte, vê serem erigidos símbolos de ostentação do Antigo Regime nos trópicos, como museus, teatros, jardins, largos, casarões, escolas, tipografias que, ao mesmo tempo em que são elementos de reafirmação de hábitos de diferenciação das nobrezas europeia e luso-brasileira em relação aos demais estratos sociais, serão ferramentas utilizadas para o questionamento da velha ordem, propiciado pelas novas sociabilidades e práticas políticas que emergem. ${ }^{29}$ Ainda que se tente manter o Império português, num esforço presente em outras monarquias absolutistas, frente ao avanço napoleônico e dos ideais revolucionários franceses, as transformações propiciadas na antiga colônia acabam por alimentar ainda mais o ambiente de insatisfação política e da busca por novos caminhos de organização das partes de um Império em ruínas. ${ }^{30}$

\footnotetext{
${ }^{27} 13 / 05 / 1808$. Carta régia ao governador e capitão general de Minas Gerais sobre a guerra aos índios botocudos. In: CUNHA, Manuela Carneiro da (org.), op. cit., 1992, p. 58-60.

${ }^{28}$ DIAS, Maria Odila da Silva. A interiorização da metrópole (1808-1853). In: MOTA, Carlos Guilherme (org.). 1822: Dimensões. São Paulo: Perspectiva, 1972, p. 160-184. Para revisões a respeito dessa afirmação clássica de Maria Odila, que nega o caráter revolucionário das transformações em curso, preferindo a análise das estruturas que se mantiveram (como a monarquia e a escravidão), ver SLEMIAN, Andréa. Vida política em tempo de crise: Rio de Janeiro (1808-1824). São Paulo: Aderaldo \& Rothschild, 2006, especialmente o cap. 1.

${ }^{29}$ SLEMIAN, Andréa, op. cit., 2006, p. 51-68.

${ }^{30}$ Para um entendimento da reinvenção do Antigo Regimena América, em que o velho trazia o novo, tem-
} 
Além de imprimir ao Rio de Janeiro o estatuto de capital, não mais da colônia, porém do próprio Império ao qual era subordinada, procurando reconstruir aqui a vida em corte, cabe ao príncipe-regente apropriar-se da real dimensão do território americano, precavendo-se de inimigos externos, do contágio das ideias de liberdade e de revolução que pudessem penetrar através da América espanhola, também em frangalhos, e através da entrada intensa de europeus de várias procedências. ${ }^{31} \mathrm{~A}$ delimitação do espaço interno da colônia requer agora avançar para regiões obstaculizadas à penetração portuguesa nos séculos anteriores. Há que se recordar que o próprio Diretório emerge no contexto de demarcação de fronteiras da América com a Coroa espanhola, especialmente nos seus limites ao norte e ao sul, o que culmina com os tratados de Madri, em 1750, e Santo Ildefonso, em 1777. Neste contexto, a cooptação e o controle das populações indígenas em região de fronteira é fundamental para garantir a posse lusa desses locais e a estratégia pombalina é transformar, gradualmente, os nativos em portugueses. Diferentemente disso, na época da reestruturação do Império português pelas mãos joaninas, busca-se não mais atrair os índios, mas retirá-los dessas regiões impenetráveis, escravizando-os e matando-os, inclusive.

Assim, passados quatro meses da fatídica chegada da corte, o príncipe-regente d. João instrui o capitão-general de Minas Gerais a decretar guerras contra os índios botocudos daquela capitania, pois eles são antropófagos e não têm aceitado a submissão ao reino por nenhum outro meio, segundo suas palavras. Para deter esse processo, d. João ordena uma guerra ofensiva sem tréguas até o momento em que todos os índios da região estejam submissos e as terras que ocupam tenham sido deles tomadas. O meio de se obter esse controle é a montagem de expedições de pedestres e de bandeiras, inclusive compostas por índios domesticados. As recompensas, além do soldo, não tardarão, segundo promete o regente: além de cativar todos os índios aprisionados, os soldados podem ser agraciados com lotes de terras e os comandantes das expedições deverão receber pagamento extra, se provarem que renderam maior número de botocudos:

se o artigo de JANCSÓ, István; MACHADO, André Roberto deA. Tempos de reforma, tempos de revolução. In: LEOPOLDINA, D. Cartas de uma imperatriz. São Paulo: Estação Liberdade, 2006, p. 28-29. ${ }^{31}$ A respeito do contato com a América espanhola, especialmente na região do Prata, no contexto de crise das monarquias ibéricas, ver o trabalho de PIMENTA, João Paulo Garrido. A política hispanoamericana e o Império português (1810-1817): vocabulário político e conjuntura. In: JANCSÓ, István (org.) Brasil: Formação do Estado e da Nação. São Paulo: Hucitec/Unijuí/Fapesp, 2003, p. 123-139. 
Ordeno-vos que a estes Comandantes se lhes confira anualmente um aumento de soldo proporcional ao bom Serviço, que fizerem, regulado este pelo princípio, que terá mais meio soldo aquele Comandante, que no decurso de um ano mostrar não somente, que no seu distrito não houve invasão alguma de Índios Botocudos, nem de outros quaisquer índios brabos, de que resultasse morte de portugueses, ou destruição de suas plantações; mas que aprisionou, e destruiu no mesmo tempo maior número, do que qualquer outro Comandante; conferindo-se aos demais um aumento de soldo proporcional ao Serviço que fizeram, servindo de base para máxima recompensa o aumento de meio soldo. ${ }^{32}$

A proposta de devastação do sertão de Minas Gerais é ocasionada tanto pela necessidade de desenvolver economicamente a região, aproveitando o curso dos rios que interligam as capitanias de Minas, Espírito Santo e Bahia (e as subsidiárias, Porto Seguro e Ilhéus) quanto pelo interesse em afastar dali as populações indígenas recalcitrantes à presença portuguesa. $\mathrm{O}$ motivo desta vasta região ter se mantido inatingível até àquela época tem relação com a mineração dos séculos anteriores e a restrição à circulação de pessoas por parte da metrópole, evitando o contrabando de ouro e a presença daqueles não autorizados a extraí-lo. Havia somente caminhos oficiais de circulação de pessoas e mercadorias e foi proibido pela Coroa o trajeto que englobava essa região de limites entre as três capitanias. Como ali estavam concentrados muitos grupos que ainda resistiam ao contato com o branco, mantendo-se em guerras para evitar sua matança, escravização ou serem aldeados, os administradores régios alimentaram durante os séculos anteriores o imaginário deste local como região inóspita, devido às corredeiras dos rios (Doce, Jequitinhonha) serem intransponíveis e os povos indígenas ali residentes serem sanguinários antropófagos. ${ }^{33}$ No entanto, segundo um levantamento antropológico mais apurado, ao se identificar os grupos ali presentes, como os pataxós ou maxakalis, é fácil perceber que se tratam de grupos do tronco macro-jê. Acontece que nenhuma destas etnias pratica canibalismo e a acusação de serem comedores de carne humana, feita pela política joanina, torna-se improcedente. Como mostrou Maria Hilda Baqueiro Paraíso, inclusive o relato que se faz das supostas atrocidades sanguinárias cometidas por estes grupos aproxima-se muito mais das

\footnotetext{
${ }_{32} 13 / 05 / 1808$. Carta régia ao governador e capitão general de Minas Gerais sobre a guerra aos índios botocudos. In: CUNHA, Manuela Carneiro da (org.), op. cit., 1992, p. 59.

${ }^{33}$ PARAISO, Maria Hilda Baqueiro. Tempo da dor e do trabalho: A conquista dos territórios indígenas nos sertões do leste. Tese de doutorado, História Social, FFLCH, Universidade de São Paulo, 1998, 5 vols.
} 
crônicas coloniais, como de Hans Staden, que descreveram hábitos dos antigos tupis, do que uma narrativa que se encaixe com os hábitos destes povos. ${ }^{34}$ Aqui também se percebe a reedição da dicotomia primordial da visão que os colonizadores tinham a respeito dos ameríndios. Os grupos aldeados eram chamados, independentes da etnia, de naknenuks, vistos como cordiais, tais como os índios kamakã-mongoiós. Em oposição, os índios hostis eram denominados de botocudos, grens ou aimorés. Dentro desse quadro, havia ainda os maxakalis que se consideravam originários de ancestral comum, mas eram compostos por diferentes etnias, como os pataxós, monoxós, maxakalis, malalis, panhames, dentre outros. ${ }^{35}$

Conforme trechos da carta régia de 13 de maio de 1808, citados anteriormente, percebe-se um nítido movimento de eliminar essa resistência dos grupos locais que insistem em continuar com seus próprios hábitos culturais, negando-se a aceitar sequer a presença dos colonizadores. Diante disso, somente o terror das armas reais pode pôr fim a essa rebeldia, visando desenvolver economicamente a região, especialmente para resolver a pobreza das capitanias do Espírito Santo, Porto Seguro e Ilhéus, abrindo a comunicação com Minas, uma das mais ricas porções da América portuguesa.

Propondo-Me igualmente por motivo destas Saudáveis Providências contra os Índios Botocudos, preparar os meios convenientes para se estabelecer para o futuro a Navegação do Rio Doce, que faça a felicidade dessa Capitania, e Desejando igualmente Procurar com a maior Economia da Minha Real Fazenda meios para tão saudável empresa; assim como Favorecer os que quiserem ir povoar aqueles preciosos Terrenos auríferos abandonados hoje pelo susto, que causam os Índios Botocudos; Sou servido Ordenar-vos nesta conformidade que na Junta, que vos Mando organizar, façais propor, e executar todos os meses os meios de Exploração do Rio Doce, seja para exame da Cachoeira, que impedem que ele seja já totalmente navegável, seja para fazer mais fácil a sua Navegação, sendo possível abreviá-la. ${ }^{36}$

Segundo esse movimento, as guerras justas de d. João aparecem como instrumentos de avanço da cultura ocidental, consolidando a posse do território e afastando as criaturas consideradas atrasadas e bestiais que ocupavam os sertões. No território da América portuguesa, tem-se em mira, a leste, o interior de Minas em suas fronteiras intercapitanias e, a oeste, os limites da capitania de São Paulo, além

\footnotetext{
${ }^{34}$ Idem, ibidem, vol. 2, p. 268-278.

${ }^{35}$ Idem, ibidem, vol. 2, p. 283-293.

${ }^{36} 13 / 05 / 1808$. Carta régia ao governador e capitão general de Minas Gerais sobre a guerra aos índios botocudos. In: CUNHA, Manuela Carneiro da (org.). op. cit., 1992, p. 59/60.
} 
da cidade de Curitiba, nos territórios mal conhecidos que terminam na fronteira com as terras de Espanha. Assim, a caracterização dos índios como elementos mortais, selvagens e carentes de controle é o elemento propulsor desse avanço a terrenos inóspitos à presença "civilizadora". Para efetuar esse intento, tudo passa a ser permitido: atribuir antropofagia àqueles grupos que não eram afeitos a tal prática, voltar à escravização dos índios, permitir matá-los. Sendo isso realmente um retrocesso em comparação com o ideário das Luzes, que propunha a incorporação dos índios como vassalos, para justificar esse recuo, nada mais eficiente do que projetar nestes grupos indígenas os atributos mais negativos possíveis.

No caso de São Paulo, tem-se um movimento desde a segunda metade do século XVIII, após a restauração da autonomia da capitania em 1765, de fazer avançar a fronteira agrícola e demarcar o território nos limites entre os dois impérios ibéricos, tentando construir no Iguatemi e em Guarapuava, pontos extremos da capitania paulista, elementos de povoamento e militarização da região. O governo do capitão-general Luís Antonio de Souza Botelho Mourão, morgado de Mateus (1765-1775), em consonância com as medidas pombalinas, procura levar a cabo tais projetos, que são malogrados. ${ }^{37} \mathrm{Na}$ virada do século XIX, vive-se ainda com esse impasse na ocupação territorial e a decretação das guerras contra os "bugres de São Paulo" propõe, à semelhança da solução mineira, o meio enfático como isso será resolvido. ${ }^{38}$

Tendo-se verificado na minha real presença a inutilidade de todos os meios humanos, pelos quais tenho mandado que se tente a sua civilização e o reduzi-los a aldear-se e gozarem dos bens permanentes de uma sociedade pacífica e doce, debaixo das justas e humanas leis que regem os meus povos, e até mostrando a experiência quanto inútil é o

\footnotetext{
${ }^{37}$ BELLOTTO, Heloisa Liberalli. Autoridade e conflito no Brasil colonial: o governo do morgado de Mateus em São Paulo. São Paulo: Secretaria de Estado da Cultura, 1979.

${ }^{38} \mathrm{O}$ início da conquista dos campos de Guarapuava ter sido implementado somente no início do século XIX é assim justificado por Rosângela Ferreira Leite: “A ocupação dessa região, já tentada na segunda metade do século XVIII, tornava-se, nos primeiros tempos da chegada da corte portuguesa ao Rio de Janeiro, projeto relevante. Tendo que romper os sertões do Tibagi, os rios Iguaçu e Uruguai, a construção de um novo caminho, ligando Sorocaba ao Rio Grande e repúblicas do Prata, era empreendimento audacioso. Além de representar uma via para a circulação de animais e produtos oriundos de Corrientes e Missões, a abertura dessa estrada garantiria reconhecimento dos vastos sertões ocidentais. Dessa forma, a colonização de Guarapuava realizada no século XIX, comumente justificada pela necessidade de 'construção de barreira frente ao avanço dos espanhóis vizinhos', assume outra dimensão, com novos interesses somando-se ao de fechamento da fronteira." LEITE, Rosângela Ferreira. Nos limites da colonização: Ocupação territorial, organização econômica e populações livres pobres (Guarapuava, 1808-1878). Tese de doutorado, História Econômica, FFLCH, Universidade de São Paulo, 2006, p. 25-26.
} 
sistema de guerra defensiva: sou servido por estes e outros justos motivos que ora fazem suspender os efeitos de humanidade que com eles tinha mandado praticar. ${ }^{39}$

Alguns meses depois das hostilidades decretadas contra os botocudos de Minas, os chamados bugres paulistas parecem merecer também o mesmo fim, segundo a visão joanina. Nas palavras do príncipe-regente, os índios de São Paulo impedem o desenvolvimento dos campos de cultivo na região de Curitiba e Guarapuava, assassinando os fazendeiros dos arredores e destruindo o caminho real que liga a zona pecuarista na capitania do Rio Grande de São Pedro à vila de Faxina, no oeste paulista. Já que os bons modos não foram eficientes para os pacificar, estabelece-se que aquele morador que aprisionar um dele poderá escravizá-lo por 15 anos. Apesar disso, d. João afirma, na sequência, que se deve mostrar aos índios que, caso queiram colocar-se voluntariamente em aliança com o reino, terão terras para cultivo e serão livres. ${ }^{40}$ Essa afirmação soa um tanto quanto irônica ou irreal na medida em que, logicamente, nenhum miliciano ou morador que pudesse, sem nenhum obstáculo, pegar para si um índio como escravo deixaria escapá-lo pelo nobre motivo do indígena servir ao rei como vassalo, principalmente numa terra em que a principal mão-de-obra disponível era esta, como o sertão paulista. Conforme analisei em outro trabalho, nas áreas periféricas da capitania, depois Província de São Paulo, especialmente nas vilas de Itapetininga, Faxina e Curitiba, os índios eram elementos fundamentais em dois sentidos. Para a criação de gado, numa região que servia de rota de passagem das tropas do sul a Sorocaba, cercada de roças de subsistência, a mão-de-obra indígena era imprescindível, já que tal local, enquanto subsidiário à grande lavoura, não podia importar mão-de-obra africana. Ao mesmo tempo, para consolidação das vilas e propriedades existentes nos sertões, a presença de grupos indígenas como kaiowás, guaranis e kaingangs era um impeditivo marcante para a manutenção das populações colonizadoras ali e a guerra ofensiva casava perfeitamente com o intuito de retirá-los do caminho. ${ }^{41}$

No entanto, para obter eficiência na implementação destes planos de conquista, tanto em Minas quanto em São Paulo, apenas as guerras justas não seriam suficientes para conter os índios e iniciar uma política de povoamento

\footnotetext{
${ }^{39} 05 / 11 / 1808$. Carta régia sobre os índios botocudos, cultura e povoação dos campos geraes de Coritiba e Guarapuava. In: CUNHA, Manuela Carneiro da (org.), op. cit., 1992, p. 62.

${ }^{40}$ Idem, ibidem, p. 63.

${ }^{41}$ SPOSITO, Fernanda, op. cit., 2006. - capítulo 4.
} 
por brancos. Assim, nos anos subsequentes, algumas outras medidas vão sendo decretadas através de outras cartas régias e colocadas em prática no nível local. De todo modo, o sentido dessa política ofensiva é bastante claro e sua revogação ainda demoraria muitas décadas, já que, dentro de uma política expansionista, parecia fazer pouco sentido deter-se em pormenores humanitários ou legais a respeito das populações indígenas, grande obstáculo à política de povoamento. Povoamento este que ironicamente se faria em cima do decréscimo populacional dos índios, ao contrário da política pombalina que os via como elemento de fomento à criação e desenvolvimento de vilas e cidades.

No caso de Minas Gerais, projeta-se a formação de uma junta que deveria cuidar tanto da civilização dos índios quanto da navegação do rio Doce, segundo a carta de 13/05/1808. No final deste mesmo ano, o príncipe-regente dá novas providências, mandando tornar devolutos os terrenos antes distribuídos em sesmarias e não cultivados, devendo ser repartidos entre os novos povoadores. O príncipe, embora mande enviar eclesiásticos para catequizar os índios da região, não incentiva que se acolham os índios que quiserem colocar-se sob sua proteção, se eles estiverem em pequeno número. Isso porque, segundo ele, a experiência do Diretório mostrou que pequenas povoações são infrutíferas e não civilizam os índios. Assim, deve-se entregá-los a fazendeiros que terão a função de agasalhá-los e instruí-los às suas custas, aproveitando-se obviamente do seu trabalho. Inclusive, caso ricos fazendeiros queiram fazer grandes povoações de indígenas, com pelo menos 1.200 casais, civilizando-os e desenvolvendo agricultura, além de incorporarem 100 casais de europeus e construírem igreja, poderiam ter sua povoação e seus estabelecimentos agraciados pelo poder régio com o título de vila. ${ }^{42}$ Através dessa iniciativa vemos a entrega a particulares de prerrogativas de povoamento e civilização antes centralizadas pela Coroa ou ordens religiosas. Sinal dos novos tempos, a iniciativa particular e a retirada dos índios do caminho, num movimento aparente de desistência da Coroa em transformar os índios em vassalos.

No entanto, há toda uma história colonial nessas terras para mostrar que uma política de dominação não se faz só de hostilidades. Não foi por acaso que a política indigenista portuguesa dos séculos anteriores se constituiu de elementos de hostilidade e pacificação, guerras e aldeamentos, mortandades e

\footnotetext{
${ }^{42} 02 / 12 / 1808$. Carta régia. Sobre a civilisação dos índios, a sua educação religiosa, navegação dos rios e cultura dos terrenos. In: CUNHA, Manuela Carneiro da (org.), op. cit., 1992, p. 66-69.
} 
proteções. Portanto, nessas novas-velhas situações evidenciadas nos sertões de Minas e São Paulo no século XIX não haveria de ser diferente. Em São Paulo, há um claro recuo de d. João que, paralelamente à escravização por 15 anos dos bugres aprisionados, projeta um plano de catequese dos índios dos campos de Guarapuava, com uma estratégia de fixar o povoamento nos moldes ocidentais que deveria ser construído ali. Assim, além da doação de sesmarias a povoadores pobres, do incentivo fiscal a qualquer pessoa que se instalasse naquela região e do envio de prisioneiros para cumprirem pena de degredo ali, também o acolhimento dos indígenas para compor a nova povoação. ${ }^{43}$

Nos campos de Guarapuava, já objeto da cobiça portuguesa desde o início da colonização portuguesa, ainda no século XVI, onde nas proximidades estavam instaladas as missões jesuíticas do Guairá e Paraná, o avanço dos luso-brasileiros segue lento, com inúmeras dificuldades logísticas, devido à precariedade de recursos e pessoal, e à resistência dos grupos indígenas que não respondem de maneira linear aos intentos da colonização. ${ }^{44} \mathrm{Em} 1810$, é fundado o aldeamento de Atalaia, sob controle do missionário Francisco das Chagas Lima e, em 1819, começa a ser construída a freguesia de Belém de Guarapuava, indicando a evolução das instalações. O missionário relata as chacinas ocorridas entre as facções que compõem os grupos indígenas da região que ele denomina de votorons, camés, dorins e xocrens. Na verdade, segundo os estudos etnológicos mais recentes, sabemos que se tratam de subgrupos da etnia kaingang, da grande família jê, que constroem sua identidade dentro da divisão do grupo em duas partes, representando as metades opostas, inimigas e complementares (exceção feita aos xocrens que seriam os xoklengs, outra etnia que no presente habita terras no interior dos estados da região sul). ${ }^{45}$

Dentro dessa lógica, nas disputas interétnicas, a guerra se faz necessária como um elemento de demarcação da fronteira identitária entre os grupos,

\footnotetext{
${ }^{43}$ 01/04/1809. Carta régia. Approva o plano de povoar os campos de Guarapuava e de civilisar os índios bárbaros que infestam aquelle território. In: CUNHA, Manuela Carneiro da (org.), op. cit., 1992, p. 69-72. ${ }^{44}$ Informações mais detalhadas a respeito da instalação dos brancos em Guarapuava estão no relato do padre que fundou o aldeamento de Atalaia na região, escrito em 1827. LIMA, Francisco das Chagas. Memória sobre o descobrimento e colônia de Guarapuava. In: SALLAS, Ana Luisa Fayet (org.). Documentação sobre os povos indigenas: Séculos XVIII e XIX. Curitiba: Aos Quatro Ventos, 2000. Agradeço a Rosângela Ferreira Leite por ter me fornecido esta publicação.

${ }^{45}$ Uma análise antropológica dos aldeamentos kaingangs, rica em seu diálogo com a história, está em AMOROSO, Marta Rosa. Catequese e evasão: Etnografia do aldeamento indígena de São Pedro de Alcântara, Paraná (1845-1895). Tese de doutorado, Antropologia Social, FFLCH, Universidade de São Paulo, 1998.
} 
como foi e é tão comum dentro da lógica ameríndia. No caso de Guarapuava, mais uma vez assistimos à ocupação luso-brasileira impondo-se frente a essa composição tática dos índios, narrando perplexa as matanças praticadas de um grupo contra outro, inclusive de aldeados que atacam seus inimigos nas matas. "Essas hordas, pelas dissensões que têm entre si, não cessam de se destruírem mutuamente", segundo avalia o missionário responsável pelo aldeamento. ${ }^{46} \mathrm{O}$ religioso, que permanece em Guarapuava até 1827, atribui às rixas entre os índios a impossibilidade do êxito de sua civilização, agravado ainda pelo isolamento e escassez de recursos da região. Essas dificuldades, tão comuns no processo de dominação dos povos indígenas pelos colonizadores, ainda perdurariam por muitas décadas, chegando ao século XX, quando a política indigenista republicana teve que pensar outras soluções a respeito dos povos indígenas que impediam o avanço das ferrovias paulistas e o devassamento do território mato-grossense, num novo surto civilizatório pela região. Isso porque, ao longo do século XIX, as relações entre os povos indígenas e os brasileiros seriam radicalmente intensificadas, com conflitos mortais e decréscimo populacional significativo dos índios até então mantidos mais afastados em relação à sociedade nacional.

Para o período em tela, em Minas Gerais, a Junta de colonização de índios e de navegação do rio Doce, auxiliada pelas divisões militares, também vivencia, ainda na década de 10 do século XIX, os impasses de conquista dos povos indígenas arredios. O comandante da Junta a partir de 1819, Guido Tomas Marlière, é uma referência no apaziguamento das hostilidades praticadas pelos colonizadores contra os índios e vice-versa, como fruto da política joanina de guerra justa, procurando, assim como tentado em Guarapuava, aldear e civilizar os botocudos, contrapondo-se a práticas ofensivas utilizadas por outros comandantes. ${ }^{47}$

Muitos pormenores a respeito das medidas posteriores adotadas poderiam ser acrescentados aqui, mas meu objetivo foi compreender o sentido das práticas iniciadas por d. João contra os índios dessa parte da América. A título de conclusão, podemos entender esses movimentos posteriores às cartas régias de 1808 como uma tentativa de amenizar o tom drástico e sanguinário das intenções joaninas que, como a colonização portuguesa há quase trezentos anos havia mostrado, não se fazia só com a espada, mas também com a cruz, numa

\footnotetext{
${ }^{46}$ LIMA, Francisco das Chagas. Memória sobre o descobrimento e colônia de Guarapuava. In: SALLAS, Ana Luisa Fayet (org.), op. cit., p. 62.

${ }^{47}$ PARAISO, Maria Hilda Baqueiro, op. cit., 1998, vol. 2, p. 323-30; vol. 3, p. 331-453.
} 
metáfora a respeito da célebre disputa sobre qual o melhor meio de sujeição dos ameríndios. Mesmo depois da expulsão dos jesuítas e laicização do controle dos aldeamentos indígenas, a iniciativa religiosa, embora não central, seria subsidiária para a plena conversão dos povos. Como se pode notar ao longo das experiências descritas aqui, os índios não podem ser simplesmente eliminados do território. Isso porque a sua resistência não seria facilmente debelada e também porque contar com sua aliança é de fundamental importância na construção dos espaços ocidentais, seja pelo conhecimento que têm das condições locais, seja por que se constituem como a principal mão-de-obra disponível.

\section{Conclusões}

Depois de percorrido este trajeto, conforme enunciado em meus objetivos iniciais, pretendo agora inferir algumas conclusões possíveis a partir da linha de análise que adotei. Se argumentei inicialmente que não seria possível entender a política joanina sem compará-la com as medidas pombalinas, pensando-as como um retrocesso ou um avanço em relação ao que ocorrera no século XVIII, reitero que as cartas régias de d. João VI contra os índios de Minas e São Paulo foram um atraso, dentro desta perspectiva comparativa.

A política joanina simbolizou uma reedição de medidas coloniais, o extermínio e a escravização indígena. Dentro do contexto revolucionário em vigor, que culminou com a formação do Estado independente do Brasil, essa solução não seria tranquilamente assumida, a partir da discussão de tema tão polêmico como cidadania, evidenciada em 1823, durante a Assembleia Constituinte. Se os destinos das populações indígenas sempre foram motivos de impasse desde o encontro com o Novo Mundo, depois da filosofia iluminista e da crise do Antigo Regime no século XVIII, esta questão toma um novo sentido. O debate conversão ou extermínio foi publicizado, por exemplo, desde Bartolomé de Las Casas versus Juan Ginés de Sepúlveda a respeito das Índias de Castela em 1550. Com a adoção da guerra justa no início do século XIX, numa escolha pelo modo mais radical de superar a política pombalina, que concebia o projeto de incorporação acelerada do índio à condição de vassalo, a solução joanina traria, no mínimo, algum desconforto com relação ao discurso político. Tanto foi assim que, conforme dito anteriormente, o próprio d. João, nos anos subsequentes, procurou avançar para além das políticas ofensivas, apontando também para a possibilidade de alianças com os grupos indígenas, a exemplo da fundação do 
aldeamento em Guarapuava e do comando, por Guido Marlière, da Junta de civilização de índios e navegação do rio Doce, ocorridos em 1819.

Outro aspecto sobre o sentido das práticas a respeito dos índios no período seria pensá-las na perspectiva das especificidades regionais. Essa abordagem nos faria voltar à ideia de que teria faltado uma política indigenista coesa para a América portuguesa ao longo de sua colonização, já que muitas das medidas régias atendem demandas dos agentes coloniais envolvidos nas conquistas de determinada parte do território americano. Assim, também quando da derrocada do império colonial, é difícil para a Coroa conjugar esforços para elaborar uma política que possa ser plenamente aplicada em toda a América. Como o Diretório tem sido problematizado como uma política que faz sentido dentro da realidade amazônica, as guerras justas podem ser enquadradas especificamente para os sertões de Minas e São Paulo, ainda que tanto uma quanto outra política tenham sido estendidas, na lei ou na prática, às outras regiões. ${ }^{48}$

No entanto, gostaria de avançar sobre essa proposição, justificando que não se trata de pensar as localidades como anomalias que destoam do centro, mas perceber que a questão indígena no século XIX é essencialmente uma questão das periferias, como analisei em meu trabalho. ${ }^{49}$ Assim, algumas afirmações de Manuela Carneiro da Cunha já vêm sendo superadas: a ideia de um "vazio legislativo" na primeira metade do século XIX e a interpretação da política indigenista deste século muito mais como política de terras do que de mão-de-obra, salvo nas regiões afastadas. ${ }^{50}$ Mas o ponto central é que a questão indígena, no limiar

\footnotetext{
${ }^{48}$ A extensão do Diretório pombalino para o restante da América portuguesa deu-se como "Direção com que interinamente se devem regular os índios das novas villas e lugares." In: Revista do Instituto Histórico e Geográfico Brasileiro, tomo 46. Rio de Janeiro: [s. e.], 1884, p. 121-171. A extensão para o Pará da carta régia de 13/05/1808 foi dada em 05/09/1811, numa outra carta a respeito de uma companhia de comércio entre Goiás e Pará. In: CUNHA, Manuela Carneiro da (org.), op. cit., 1992, p. 79-80. ${ }^{49}$ A discussão a respeito das práticas políticas para as populações indígenas na primeira metade do século XIX, superando a ideia de "vazio legislativo", pode ser encontrada em minha dissertação de mestrado. SPOSITO, Fernanda, op. cit., 2006, especialmente nos capítulos 2 e 3.

50 “'A 'questão indígena', no século XIX, deixou de ser uma questão de mão-de-obra, para se converter essencialmente numa questão de terras. Há variações regionais, é claro: na Amazônia, onde a penúria de capitais locais não permitiu a importação de escravos africanos, o trabalho indígena continuou sendo fundamental, e foi reaviventado no final do século, com a exploração da balata, da borracha e do caucho. No Mato Grosso e no Paraná, ou mesmo em Minas Gerais e no Espírito Santo, as rotas fluviais a serem descobertas e consolidadas exigiriam a submissão dos índios na região. (...) A legislação indigenista do século XIX, sobretudo até 1845, é flutuante, pontual e, como era de se esperar, em larga medida subsidiária de uma política de terras. Com a revogação, em 1798, do Diretório Pombalino, promulgado na década de 1750, havia-se criado um vazio que não seria preenchido. Só em 1845, com o 'Regulamento acerca das missões de catechese e civilisação
} 
do século XIX, só existe realmente como um problema relevante nas periferias, nas áreas de expansão de fronteira. Ali, a mão-de-obra indígena, assim como a sua terra, ainda é fundamental, conforme analisei em minha dissertação de mestrado. Pude perceber que, invariavelmente, quando os parlamentares brasileiros das décadas de 20 a 40 do século XIX tentaram elaborar políticas a respeito das populações indígenas, as questões da mão-de-obra ou da apropriação territorial estavam intimamente ligadas ao tema. Tanto é que a primeira política a respeito dos índios do Império do Brasil, o Decreto n. 426 (que contém o regulamento acerca das missões de catequese e civilização dos índios), seria implementada em 24/07/1845, justamente quando o $2^{\circ}$ Reinado começaria estabelecer diretrizes para a questão do tráfico negreiro, da política imigratória e da questão de terras. ${ }^{51}$

Por isso, não me parece a solução mais eficiente para se pensar a questão das populações indígenas atrelá-la unicamente a uma dimensão local. É isso que faz Patrícia de Mello Sampaio, ao tentar rebater a posição de Cunha, pois acaba reduzindo o problema às fronteiras regionais, procurando pensá-lo dentro da Amazônia portuguesa. ${ }^{52}$ Assim, embora as soluções para os enfrentamentos dos luso-brasileiros contra os índios tenham arranjos regionais, conforme propõe Sampaio, fazem todas parte de um mesmo processo de consolidação das fronteiras em áreas de alta densidade demográfica indígena no Império, antes português e, depois, dentro da construção do Império do Brasil. Segundo o que procurei demonstrar neste artigo, num momento de radicalização por Pombal na Amazônia, a alternativa proposta é a aliança, via vassalagem. Na sequência, com o governo joanino olhando para o sul do território, é escolhida a via não menos radical do extermínio. Ainda que ambas acabassem flexibilizadas na

dos índios' (Decreto n 426 de 24/07/1845), é que se tentará estabelecer as diretrizes sérias, mais administrativas, na realidade, do que políticas, para o governo dos índios aldeados." CUNHA, Manuela Carneiro da. Introdução. In: CUNHA, Manuela Carneiro da (org). Legislação indigenista no século XIX: Uma compilação (1808-1889). São Paulo: Edusp/Comissão Pró-Índio, 1992, p. 4 e 9. ${ }^{51}$ O Decreto ${ }^{\circ} 426$, de 24/07/1845, está publicado na compilação organizada por Manuela Carneiro da Cunha, op. cit., 1992, p. 191-9.

${ }^{52}$ Sobre as proposições de Cunha, citadas acima: "Se a rota da questão indígena mudou em boa parte do Brasil, isso não aconteceu no Grão-Pará. Ao contrário. A Carta Régia surgiu em função da conjuntura paraense e, nesse sentido, sua especificidade comprometia sua aplicabilidade em outras áreas do país, restringindo seu caráter de política indigenista geral da Coroa e configurando-se como uma legislação que ainda daria grande ênfase à questão da disponibilidade de trabalhadores, permitindo considerá-la uma legislação adequada para o período de seu funcionamento, isto é, entre 1798 e 1838." SAMPAIO, Patrícia Melo. Administração colonial e legislação indigenista na Amazônia portuguesa. In: PRIORE, Mary del; GOMES, Flávio (orgs.), op. cit., p. 136. 
prática, implicando na agressão aos povos indígenas no período pombalino e na conciliação com os índios na época joanina, estes sentidos distintos são a marca principal de cada uma das políticas indigenistas. Demonstrar e compreender essa distinção foi o meu objetivo aqui.

\section{Referências bibliográficas}

\section{Fontes}

Carta régia de 12 de maio de 1798 sobre a civilisação dos indios. In: Revista do Instituto Histórico e Geográfico Brasileiro, tomo 19. Rio de Janeiro: Laemmert, 1856, p. 313-325.

CUNHA, Manuela Carneiro da (org.) Legislação indigenista no século XIX: Uma compilação (1808-1889). São Paulo: Edusp/Comissão Pró-Índio, 1992.

Directorio que se deve observar nas Povoaçoens de Índios do Pará e Maranhão, enquanto Sua Magestade não mandar o contrário. In: MOREIRA NETO, Carlos de Araújo. Índios da Amazônia: de maioria a minoria (1750-1850). Petrópolis: Vozes, 1988, p. 166-205.

Ley porque V. Magestade ha por bem restituir aos Indios do Graõ Pará, e Maranhaõ a liberdade das suas pessoas, bens e commercio na fórma que nella se declara. 06/06/1755. In: MOREIRA NETO, Carlos de Araújo. Índios da Amazônia: de maioria a minoria (1750-1850). Petrópolis: Vozes, 1988, p. 152-162.

LIMA, Francisco das Chagas. Memória sobre o descobrimento e colônia de Guarapuava. (1827) In: SALLAS, Ana Luisa Fayet (org.). Documentação sobre os povos indígenas: Séculos XVIII e XIX. Curitiba: Aos Quatro Ventos, 2000.

\section{Bibliografia}

ALENCASTRO, Luiz Felipe de. O trato dos viventes: Formação do Brasil no Atlântico Sul. São Paulo: Companhia das Letras, 2000.

ALMEIDA, Rita Heloísa de. O Diretório dos Índios: Um projeto de "civilização" no Brasil do século XVIII. Brasília: Ed. UnB, 1997.

AMOROSO Marta Rosa. Catequese e evasão: Etnografia do aldeamento indígena de São Pedro de Alcântara, Paraná (1845-1895). Tese de doutorado, Antropologia Social, FFLCH, Universidade de São Paulo, 1998.

BELLOTTO, Heloisa Liberalli. Autoridade e conflito no Brasil colonial: o governo de morgado de Mateus em São Paulo. São Paulo: Secretaria de Estado da Cultura, 1979.

BELLOTTO, Heloisa Liberalli. Política indigenista no Brasil colonial (1570-1757). In: Revista do IEB, n 29. São Paulo, 1988, p. 29-49.

COELHO, Mauro Cezar. Do sertão para o mar: Um estudo sobre a experiência portuguesa na América, a partir da colônia. O caso do Diretório dos Índios (1751-1798). Tese de doutorado, História Social, FFLCH, Universidade de 
São Paulo, 2005.

CUNHA, Manuela Carneiro da. Introdução. In: CUNHA, Manuela Carneiro da. (org). Legislação indigenista no século XIX: Uma compilação (1808-1889). São Paulo: Edusp; Comissão Pró-Índio, 1992.

DIAS, Maria Odila da Silva.Ainteriorização da metrópole(1808-1853). In: MOTA, Carlos Guilherme (org.). 1822: Dimensões. São Paulo: Perspectiva, 1972, p. 160-184.

DOMINGUES, Ângela. Quando os índios eram vassalos: Colonização e relações de poder no norte do Brasil na segunda metade do século XVIII. Lisboa: Comissão Nacional para as Comemorações dos Descobrimentos Portugueses, 2000.

FARAGE, Nádia. As muralhas do sertão: Os povos indígenas no Rio Branco e a colonização. Rio de Janeiro: Paz e Terra/Anpocs, 1991.

HOLANDA, Sérgio Buarque de. A herança colonial, sua desagregação. In: HOLANDA, Sérgio Buarque de. (org.) História geral da civilização brasileira, tomo 2, vol. 1. Rio de Janeiro: Bertrand Brasil, 1997, p. 10-39.

JANCSÓ, István (org.) Cronologia de história do Brasil monárquico. (1808-1889). São Paulo: Humanitas/FFLCH-USP, 2000.

JANCSÓ, István; MACHADO, André Roberto de A. Tempos de reforma, tempos de revolução. In: LEOPOLDINA, D. Cartas de uma imperatriz. São Paulo: Estação Liberdade, 2006, p. 17-49.

JANCSÓ, István; PIMENTA, João Paulo G. Peças de um mosaico ou apontamentos para o estudo da emergência da identidade nacional brasileira. In: MOTA, Carlos Guilherme (org.). Viagem incompleta: A experiência brasileira (1500-2000). Formação: histórias. $2^{\mathrm{a}}$ ed. São Paulo: Senac, 2000, p. 129-175.

KANTOR, Iris. Legislação indigenista, reordenamento territorial e autorrepresentação das elites (1759-1822). In: KOERNER, Andrei (org.). História da Justiça Penal no Brasil: pesquisas e análises. São Paulo: IBCCRIM, 2006, p. 29-38.

LEITE, Rosângela Ferreira. Nos limites da colonização: Ocupação territorial, organização econômica e populações livres pobres (Guarapuava, 1808-1878). Tese de doutorado, História Econômica, FFLCH, Universidade de São Paulo, 2006.

MACHADO, André Roberto de Arruda. A quebra da mola real das sociedades. A crise política do Antigo Regime português na Província do Grão-Pará (1821-1825). Tese de doutorado, História Social, FFLCH, Universidade de São Paulo, 2006.

MEDICCI, Ana Paula. Entre a "decadência" e o "florescimento": A capitania de São Paulo na interpretação de memorialistas e autoridades públicas (17821822). Dissertação de mestrado, História Social, FFLCH, Universidade de São Paulo, 2005.

MONTEIRO, John Manuel. A memória das aldeias de São Paulo. Índios, paulistas e portugueses em Arouche e Machado de Oliveira. In: Dimensões: Revista de História da UFES, 14, 2002, p. 17-35. 
MONTEIRO, John Manuel. Negros da terra: Índios e bandeirantes nas origens de São Paulo. São Paulo: Companhia das Letras, 2000.

NOVAIS, Fernando A. Portugal e Brasil na crise do antigo sistema colonial (17771808). $7^{\mathrm{a}}$ ed. São Paulo: Hucitec, 2002.

PARAISO, Maria Hilda Baqueiro. Tempo da dor e do trabalho: A conquista dos territórios indígenas nos sertões do leste. Tese de doutorado, História Social, FFLCH, Universidade de São Paulo, 1998, 5 vols.

PERRONE-MOISÉS, Beatriz. Índios livres e índios escravos. Os princípios da legislação indigenista do período colonial (séculos XVI e XVIII). In: CUNHA, Manuela Carneiro da (org.). História dos índios no Brasil. $2^{\mathrm{a}}$ ed. São Paulo: Companhia das Letras/Secretaria Municipal de Cultura/Fapesp, 1998, p. 115-132.

PERRONE-MOISÉS, Beatriz. Verdadeiros contrários: guerras contra o gentio no Brasil colonial. In: Sexta-Feira, v. 7, São Paulo, 2003, p. A24-A34.

PIMENTA, João Paulo Garrido. A política hispano-americana e o Império português (1810-1817): vocabulário político e conjuntura. In: JANCSÓ, István (org.) Brasil: Formação do estadoe da nação. São Paulo:Hucitec/Unijuí/Fapesp, 2003, p. 123-139.

PUNTONI, Pedro. A guerra dos bárbaros: Povos indígenas e a colonização do sertão nordeste do Brasil (1650-1720). São Paulo: Hucitec/Edusp/Fapesp, 2002 .

SAMPAIO, Patrícia Melo. Administração colonial e legislação indigenista na Amazônia portuguesa. In: PRIORE, Mary del \& GOMES, Flávio (orgs.) Os senhores dos rios: Amazônia, história e margens. Rio de Janeiro: Campus, 2003, p. 123-139.

SERRÃO, Joel. Dicionário de história de Portugal. Porto: Figueirinhas, 2002, vol. 3.

SILVA,Ana Rosa Cloclet da. Inventando a nação: Intelectuais ilustrados e estadistas lusobrasileiros na crise do Antigo Regime português. São Paulo: Hucitec/Fapesp, 2006.

SLEMIAN, Andréa. Vida política em tempo de crise: Rio de Janeiro (1808-1824). São Paulo: Aderaldo \& Rothschild, 2006.

SPOSITO, Fernanda. Nem cidadãos, nem brasileiros. Indígenas na formação do Estado nacional brasileiro e conflitos na Província de São Paulo (1822-1845). Dissertação de mestrado, História Social, FFLCH, Universidade de São Paulo, 2006.

Recebido: janeiro/2009 - Aprovado: junho/2009 